\title{
„ALKOHOLOVÝ ZÁMEK“ - NOVÝ NÁSTROJ PREVENCE ŘÍZENÍ POD VLIVEM ALKOHOLU A VYBRANÉ SOUVISEJÍCÍ PRÁVNÍ ASPEKTY
}

\author{
JAN SCHEUER ${ }^{1,2}$
}

\begin{abstract}
ABSTRAKT
Řizení vozidla pod vlivem alkoholu je v České republice protiprávním jednáním. Alkohol negativně ovlivňuje způsobilost řidiče a v důsledku toho snižuje bezpečnost silničního provozu. Článek představuje tzv. program alkoholového zámku, což je opatření, které může přispět ke snižování smutných statistik. Po obecném představení autor využívá komparaci několika evropských států, kde je tento institut již využíván, a upozorňuje na vybrané klíčové právní problémy, čímž článek může přispět do diskuze o zavedení alkoholového zámku v podmínkách České republiky.
\end{abstract}

\section{KLÍČOVÁ SLOVA}

Alkohol, alkoholový zámek, bezpečnost v dopravě, dvojí trestání, individualizace trestu, nulová tolerance

\section{ABSTRACT}

Drink-driving is a law infringement in the Czech Republic because alcohol has a negative influence on the competence of the driver to exercise the driving task.

Mgr. Jan Scheuer je student doktorského studia na Právnické fakultě MU (katedra správní vědy a správního práva) a působí v Centru dopravního výzkumu, v. v. i. Kontaktní email: 370659@mail.muni.cz.

2 Autor vřele děkuje recenzentům za podnětné připomínky, které přispěly výsledné podobě textu. 
This article focuses on the alcohol interlock program which already exists in several member countries of European Union as a method to improve road safety and it brings up selected legal questions.

\section{KEYWORDS}

Alcohol, Alcohol Interlock, Road Safety, Double Punishment, Individualisation of Punishment, Zero Tolerance

\section{1. ÚVODEM O „VESELÉM ŘIDIČI“ A JEHO VLIVU NA BEZPEČNOST SILNIČNÍHO PROVOZU}

Z dopravně bezpečnostního pohledu je alkohol prvkem, který není slučitelný $s$ bezpečným silničním provozem. Působí na psychiku člověka a ovlivňuje jeho schopnosti, což je významné zejména při výkonu činností, které jsou z určitého pohledu náročné a nebezpečné, např. při řízení vozidla. Řízení lze jako komplexní proces rozčlenit na tři úrovně. Kontrolní, taktickou a strategickou. ${ }^{3}$ V první úrovni se řidič zejména soustředí na udržení rychlosti a směru. Na taktické úrovni jsou přijímána řešení aktuálních dopravních situací. Strategická úroveň zahrnuje mimo jiné rozhodnutí, zda řídit nebo nikoliv. Je zřejmé, že řízení vozidla $v$ provozu vyžaduje velkou míru soustředění (kontrolní úroveň) a pohotovost při vyhodnocování informací (taktická úroveň). Alkohol ovlivňuje výkon řidiče ve všech třech úrovních.

Poměr dopravních nehod v České republice za rok $2016^{4}$, kdy byl u viníka zjištěn vliv alkoholu, je k celkovému počtu dopravních nehod na první pohled téměř zanedbatelný, jelikož se jedná o necelých 4,5 \%. Při bližším prozkoumání ovšem zjistíme, že na závažných následcích (usmrcení) se

\footnotetext{
3 MICHON, John A. A critical view of driver behavior models: What do we know? What should we do? In. L. Evans et al. (eds.). Human Behavior and Traffic Safety. Plenum Press, New York, 1985, s. 489. Dostupné i online z: http://jamichon.nl/jam_writings/1985_criticial_view.pdf

4 Přehled o nehodovosti na pozemních komunikacích v České republice za rok 2016. Ředitelství služby dopravní policie Policejního prezidia České republiky [online]. [cit. 14. 11. 2017]. Dostupné z: http://www.policie.cz/clanek/statistika-nehodovosti-900835.aspx? $\mathrm{q}=$ Y2hudW09Mg\%3d\%3d
} 
alkohol podílel z téměř $10 \%$. Lze vyvozovat, že dopravní nehody způsobené vlivem alkoholu jsou svým charakterem více (společensky) škodlivé.

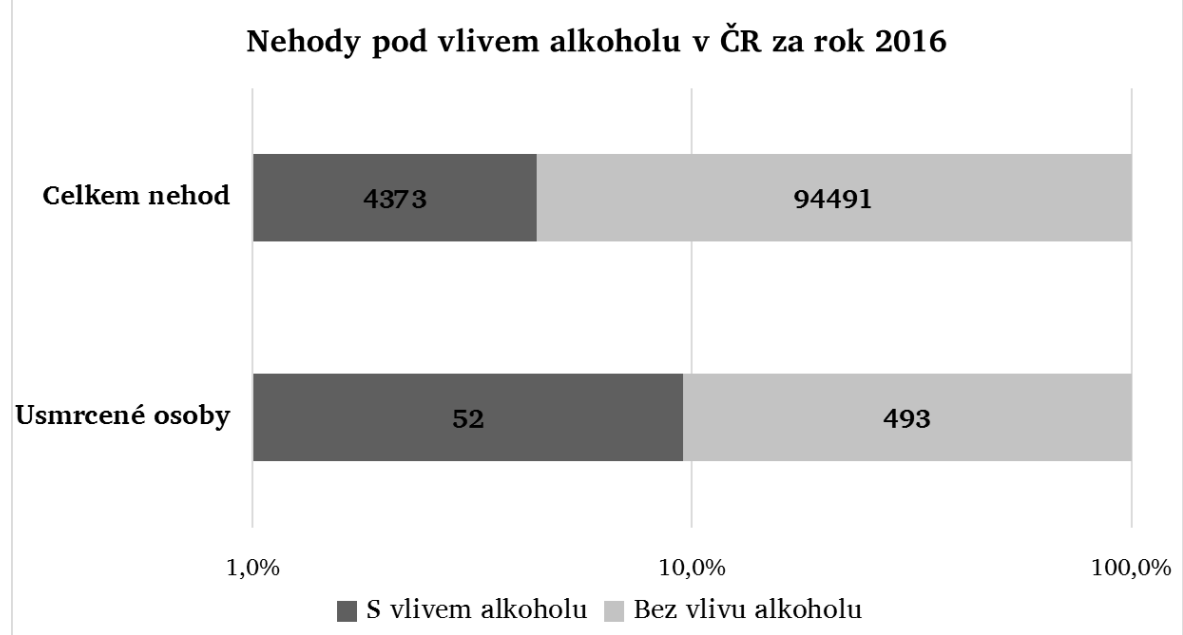

Graf 1 - Poměry počtu nehod a usmrcených osob s vlivem alkoholu.

Šokující skutečností je, že u více než $60 \%$ nehod zaviněných vlivem alkoholu byla $\mathrm{u}$ řidiče zjištěna př́tomnost alkoholu $1,5 \%$ a více. Tato kategorie opilých řidičů navíc má na svědomí usmrcení více než poloviny všech obětí nehod způsobených vlivem alkoholu.

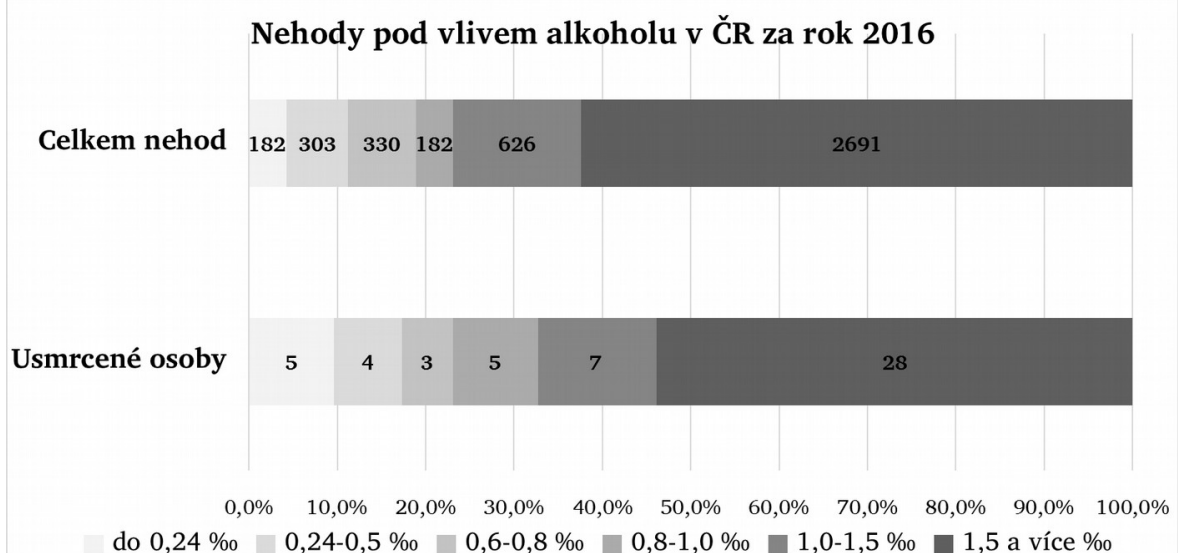

Graf 2 - Poměry počtu nehod a usmrcených osob dle zjištěné hladiny alkoholu. 
Z evropského hlediska je alkohol za volantem rovněž palčivým tématem, jelikož dle odborného odhadu ${ }^{5}$ je spojen přibližně se čtvrtinou všech úmrtí na evropských silnicích. V roce 2016 přitom přišlo na silnicích v Ev-

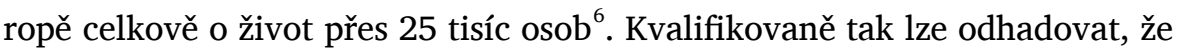
$\mathrm{v}$ průměru v evropských zemích zahyne v silničním provozu vinou alkoholu každý týden 122 osob.

Česká republika prosazuje tzv. nulovou toleranci alkoholu za volantem. ${ }^{7}$ Přestože výslovně toto slovní spojení v legislativě nenajdeme, tak tendence $\mathrm{k}$ tomuto př́istupu lze dle mého názoru vysledovat dlouhodobě. Již $\mathrm{v}$ roce 1951 tehdejší vyhláška o pravidlech silničního provozu ${ }^{8}$ stanovila, že řidič nesmí ŕídit vozidlo, pokud by jeho schopnost byla „snížena“ (zejména po požití alkoholického nápoje nebo únavou), zatímco předchozí pravidla silničního provozu hovořila o „podstatném snížení“9 ${ }^{9}$. Na základě čistě jazykového výkladu je zřejmé, že původní přístup je nulové toleranci vzdálenější. Další (legislativní) posílení nulové tolerance znamenal rok 1990, kdy legislativa opustila koncept „snížení“ způsobilosti v důsledku vlivu alkoholu a nově zakázala řidiči ř́́dit vozidlo i v době, kdy by mohl být ještě pod vlivem alkoholu ${ }^{10}$.

Nulová tolerance de lege lata vyplývá z ustanovení $§ 5$ odst. 2 písm. a) a b) zákona o silničním provozu ${ }^{11}$, která zakazují požití alkoholického nápoje při jízdě, bezprostředně před jízdou a $v$ takové době před jízdou, kdy by vliv alkoholu na řidiče mohl zasahovat i do doby jízdy. Zákon o si-

5 COWI, SWOV, ADV. Study on the Prevention of Drink-Driving by the use of alcohol interlock devices [online]. 2014, s. 28-34, [cit. 22. 5. 2017]. Dostupné zde: https://ec.europa.eu/transport/road_safety/sites/roadsafety/files/newspdf/study_alcohol_in terlock.pdf

6 Road Safety: Encouraging results in 2016 call for continued efforts to save lives on EU roads. European Commission - Press Release [online]. 28. 3. 2017, [cit. 22. 5. 2017]. Dostupné z: http://europa.eu/rapid/press-release_IP-17-674_en.htm

7 V článku není věnována pozornost „faktické“ toleranci alkoholu za volantem, která vychází z fyziologické hladiny alkoholu, která může být u člověka přítomna i bez konzumace alkoholového nápoje.

8 § 4 odst. 3 písm. c) vyhlášky č. 327/1951 Ú.I.I, kterou se stanoví pravidla silničního provo$\mathrm{zu}$.

9 Např. $\S 38$ odst. 1 zákona č. 81/1935 Sb. z. a n., o jízdě motorovými vozidly.

${ }^{10} \S 5$ odst. 2 písm. b) vyhlášky č. $99 / 1989$ Sb., o pravidlech provozu na pozemních komunikacích (pravidla silničního provozu). 
lničním provozu obsahuje vlastní legislativní zkratku pro pojem „alkoholický nápoj“ a považuje za něj i jinou látku, která obsahuje alkohol, zakazuje tedy řidiči požití alkoholu $v$ jakékoliv podobě. $Z$ uvedeného je zřejmé, že př́stup českého zákonodárce $\mathrm{k}$ alkoholu za volantem je mimořádně přísný, což deklaruje společenský postoj k eliminaci závažných následků na životech a zdraví způsobených vlivem alkoholu v silničním provozu. Českou republiku lze v tomto směru označit za jednoho z pionýrů mezi evropskými státy, jelikož nulová tolerance je aplikována spíše menšinově a vedle nás se řadí pouze Slovensko, Rumunsko a Mad’arsko. ${ }^{12}$ Mezinárodní srovnávací výzkumy dokonce ukazují, že v České republice je nejvyšší povědomí o hranici alkoholu za volantem ve srovnání s ostatními evropskými státy $^{13}$. I na této skutečnosti má jistě zásluhu „tradice“ nulové tolerance v naší legislativě.

Obecně je snižování vlivu alkoholu na bezpečnost silničního provozu jednou ze součástí komplexního systémového přistupu směřujícího $\mathrm{k}$ ideálnímu (filosofickému) cíli, který vychází ze švédské „Vize Nula“"14. Právě komplexní př́istup a vzájemná kombinace různých (i neprávních ${ }^{15}$ ) metod má potenciál akcelerovat naplňování tohoto cíle. Nastavení zákonného limitu na množství alkoholu za volantem, tak můžeme považovat pouze za jedno z mnoha opatření. Z dopravně bezpečnostního pohledu jsou společensky nejzávažnější skupinou ti, kteří se dopustí řízení pod vlivem alkoho-

11 Zákon č. 361/2000 Sb., o provozu na pozemních komunikacích a o změnách některých zákonů (zákon o silničním provozu), ve znění pozdějších předpisů („zákon o silničním provo$\mathrm{zu}$ “).

12 Blood Alcohol Content (BAC) Drink Driving Limits across Europe. ETSC [online], naposledy akt. v červnu 2016, [cit. 27. 2. 2017]. Dostupné z: http://etsc.eu/blood-alcohol-contentbac-drink-driving-limits-across-europe/

13 Eurobarometr - EU citizens' attitudes towards alcohol. European Comission [online], 2010. [19. 3. 2017], s. 33. Dostupné zde: http://ec.europa.eu/health//sites/health/ files/alcohol/docs/ebs_331_en.pdf

${ }^{14}$ Cílem je eliminace všech závažných následků dopravních nehod. BELIN, Matts-Ake a kol. The Vision Zero and its Consequences [online]. 1997, [cit. 22. 5. 2017]. Dostupné z: http://www.trafikverket.se/contentassets/5e3d8c0eb4e94efd9738cca74b912bf5/vz_and_its _consequenses.pdf

15 Např. osvětové kampaně (nizozemská kampaň „Bob“). Viz Rien bu! Merci BOB. Youtube [online]. Publikováno 2. 12. 2016, [cit. 10. 5. 2017]. Dostupné z: https://www.youtube.com/watch?v $=$ J-Bli-P0S1k 
lu ve formě úmyslu (rozhodnutí učiněno na strategické úrovni). Takový účastník silničního provozu se vědomě rozhodne, že nechce a nebude respektovat nastavená pravidla. Není sporu o tom, že tato společensky závažná kategorie řidičů existuje a je problematická, což vyplývá např́klad z grafu č. 2, kde je znázorněno, že u většiny viníků dopravních nehod způsobených vlivem alkoholu v roce 2016 byla zjištěná hladina alkoholu velmi výrazná (možnost, že by řidič o tomto ovlivnění nevěděl, je $\mathrm{v}$ zásadě vyloučena). Zejména pro tyto rizikové řidiče je třeba aplikovat efektivní opatření, které je umístí mimo ohrožující postavení v silničním provozu, ale zároveň má potenciál (pře)vychovávat ve vztahu ke strategickému rozhodování řidiče a v konečném důsledku také odpouštět. ${ }^{16}$

Tento článek se na následujících řádcích bude věnovat novému institutu s tímto potenciálem - alkoholovému zámku - který se pozvolna začíná aplikovat napříč evropskými státy jako efektivní nástroj pro potlačování vlivu alkoholu na silniční provoz. Jeho konkrétní legislativní podoba se liší země od země, a pro Českou republiku se naskytuje jedinečná př́ležitost, aby při jeho vlastní implementaci vyšla z předchozích zkušeností ostatních států. Cílem tohoto článku je také upozornění na některé právní problémy s tímto institutem spojené a obecné přispění do diskuze nad tímto novým opatřením.

\section{ALKOHOLOVÝ ZÁMEK - VIZE NEBO REALITA?}

Základní funkcionalita alkoholového zámku (angl. alcohol ignition interlock, zkráceně alcolock) spočívá v zajištění toho, že motor vozidla nebude nastartován, pokud osoba, která vozidlo startuje, není střízlivá, jelikož do alcolo$c k u$ je třeba dýchnout a př́stroj podle vyhodnocení přítomnosti alkoholu vozidlo bud' umožní nastartovat, nebo ne. ${ }^{17}$ Alcolock nezakazuje řízení plošně jako je tomu v případě uložení zákazu činnosti, ale vztahuje se pou-

\footnotetext{
${ }^{16}$ Srov. MIKULíK, Josef a kol. Bezpečnost silničního provozu - aktuální poznatky. I. díl, Centrum dopravního výzkumu, 2011, s. 30.

17 Pro maximální efektivitu tohoto institutu bývá doplněn „ochrannými“ mechanismy. Např. V některých státech USA hrozí osobám, které se nějakou formou účastní obcházení alkoholového zámku pokuty nebo odnětí svobody. Alkoholové zámky bývají také vybaveny zařízením, které udělá fotografii osoby, která do zařízení dýchá.
} 
ze na řízení pod vlivem alkoholu a řidič, který může řídit pouze vozidla vybavená alcolockem, má tuto skutečnost označenou v řidičském průkazu speciálním kódem (poslední změna směrnice o řidičských průkazech ${ }^{18}$ stanovila pro „alkoholový imobilizér“" mezinárodní kód „69“).

Proti tomuto institutu lze namítat, že může existovat řada možností, jak ho obejít. V první řadě je ale myslím důležité poukázat na to, že aktuálně uplatňované opatření, kterým pachatele umístujeme mimo ohrožující postavení (zákaz činnosti), vytváří usvědčenému pachateli právní překážku, kterou je poměrně snadné překonat a řídit vozidlo (pod vlivem alkoholu) dál, což samozřejmě má vliv na jeho výchovnou funkci. Přidaná hodnota alcolocku tedy spočívá již minimálně $\mathrm{v}$ tom, že konstruuje překážku faktickou, jejíž obejití je $z$ povahy věci spojeno $s$ většími obtížemi a $v$ závislosti na konkrétním technickém provedení je obcházení přístroje minimalizováno dalšími způsoby (přístroj dělá snímek osoby, která do něj dýchá; přistroj vyžaduje náhodné/pravidelné kontroly i v průběhu jízdy; přístroj eviduje, zapnutí motoru i v případě, že řidič nedýchnul do alcolocku; přístroj pozná umělý zdroj „dechu“ apod. ${ }^{19}$ ).

Vzhledem $\mathrm{k}$ výše uvedenému není velkým překvapením, že dosavadní výsledky výzkumů ukazují mnohem lepší účinek alcolocku v oblasti snížení recidivy, než je tomu u klasických sankčních opatření (zejm. u zákazu

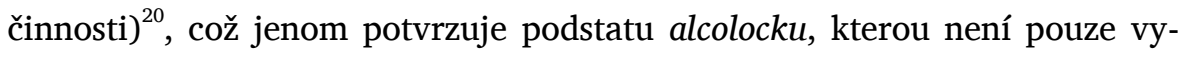
loučení z výkonu určité činnosti pod vlivem alkoholu, ale zejména také naučení nových návyků (oddělení konzumace alkoholu a řízení motorového vozidla) - vyznačuje se tedy silnými preventivně-výchovnými prvky. $\mathrm{Z}$ těchto důvodů se program alkoholového zámku stále rozšiřuje a realizují

${ }^{18}$ Směrnice Evropského parlamentu a Rady 2006/126/ES ze dne 20. prosince 2006 o řidičských průkazech (přepracované znění), ve znění účinném od 15. 5. 2015. In: EUR-Lex. Dostupné z: http://eur-lex.europa.eu/legal-content/CS/ALL/?uri=CELEX:02006L012620150515

19 Srov. např. FAQ. Lifesaver [online]. 2017, [cit. 20. 11. 2017]. Dostupné z: https://www.lifesafer.com/support/frequently-asked-questions/

${ }^{20}$ ELDER, Randy W. a kol. Effectiveness of Ignition Interlocks for Preventing Alcohol-Impaired Driving and Alcohol-Related Crashes [online]. 2011, [cit. 10. 3. 2017]. Dostupné z: https://www.thecommunityguide.org/sites/default/files/assets/PIIS07493797100071051.p $\mathrm{df}$ 
ho již v mnoha evropských státech - Švédsko, Dánsko, Finsko, Francie, Nizozemí, Belgie, Polsko a Rakousko (zavedeno v září $\left.2017^{21}\right)^{22}$.

Téma je aktuální ${ }^{23}$ i v České republice, jelikož koncepční materiál pro bezpečný silniční provoz - Národní strategie bezpečnosti silničního provozu (2011 - 2020) - uvádí, že pro dosažení stanovených cílů v oblasti ovlivnění alkoholem a jinými návykovými látkami by měly být do vozidel postupně zabudovány systémy, které znemožní nastartování řidičem pod vlivem alkoholu. ${ }^{24} \mathrm{~V}$ revizi tohoto koncepčního materiálu, která byla v roce 2017 schválena usnesením vlády ${ }^{25}$, je již nově koncipováno i konkrétní opatření akčního plánu, které nese název: „Legislativní zavedení alkolocku jako účinného technického řešení pro zamezení jízdy pod vlivem alkoholu, zvláště u profesionálních a recidivujicích řidiču. " Termín, do kterého by toto opatření mělo být v České republice realizováno, je stanoven do roku $2020{ }^{26}$

Zavedení alkoholového zámku u profesionálních řidičů nebude předmětem dalšího rozboru, jelikož alcolock v tomto případě nemá „sankční“ povahu, spíše by se mělo jednat o preventivní a kontrolní opatření ze strany zaměstnavatele. Na následujících řádcích se budu věnovat některým legislativním otázkám zavedení alcolocku v souvislosti s protiprávním řízením pod vlivem alkoholu v souladu s deklarovaným účelem článku.

${ }^{21}$ KALTENEGGER, Armin. Alternative probation system (APS) in Austria [online]. KFV Austrian Road Safety Board, 17. 10. 2017, [cit. 20. 11. 2017]. Dostupné z: http://etsc.eu/wpcontent/uploads/KALTENEGGER_ABS_EN_ETSC_Bern.pdf

22 HOUWING, Sjoerd. Alcohol Interlocks and Drink Driving Rehabilitation in the European Union. ETSC [online]. 2016, [cit. 22. 5. 2017], s. 6. Dostupné z: http://etsc.eu/alcohol-interlocksand-drink-driving-rehabilitation-in-the-eu-guidelines-for-member-states/

${ }^{23}$ Mimo jiné i viz Policie si v Jihomoravském kraji došlápla na řidiče autobusů, chytla šest opilých. Novinky.cz [online], 23. 1. 2017, [cit. 10. 3. 2017]. Dostupné z: https://www.novinky.cz/krimi/427224-policie-si-v-jihomoravskem-kraji-doslapla-naridice-autobusu-chytila-sest-opilych.html

${ }^{24}$ Národní strategie bezpečnosti silničního provozu 2011 - 2020. Ministerstvo dopravy, samostatné oddēlení BESIP [online], [cit. 10. 3. 2017], s. 65. Dostupné z: http://www.ibesip.cz/data/web/soubory/nsbsp-2011-2020-formatovani-ii.pdf

${ }^{25}$ Usnesení vlády č. 160 ze dne 27. 2. 2017 o Revizi a aktualizaci Národní strategie bezpečnosti silničního provozu na období let 2011 až 2020 s platností od roku 2017. In: Aplikace o/dok. Dostupné z: https://apps.odok.cz/attachment/-/down/RCIAAK4B536X

${ }^{26}$ Revize a aktualizace Národní strategie bezpečnosti silničního provozu 2011 - 2020, s platností od roku 2017. Ministerstvo dopravy, samostatné oddělení BESIP [online], [cit. 9. 6. 2017], s. 77. 


\section{VYBRANÉ ASPEKTY LEGISLATIVNÍHO NASTAVENÍ PROGRAMU ALKOHOLOVÉHO ZÁMKU}

Přestože i na půdě Evropské unie probíhají debaty ${ }^{27}$ o plošném zavedení alcolocků, doposud v této oblasti neexistuje absolutní unifikace, proto mohou být v národních legislativách upraveny různě. Pro navržení programu alkoholového zámku bylo identifikováno několik klíčových bodů ${ }^{28}$, které je třeba při navrhování programu náležitě promyslet, nicméně v rámci následujících podkapitol se s pomocí jednoduchého komparativního pohledu ${ }^{29}$ zaměřím pouze na vybrané legislativní otázky. Komparativní pohled bude následován (doplněn) úvahami de lege ferenda v další kapitole č. 4.

\subsection{SOUČÁST SPRÁVNÍHO NEBO TRESTNÍHO PRÁVA ANEB RIZIKO DVOJÍHO TRESTÁNÍ}

Pokud se zamýšlíme nad legislativní úpravou uložení alkoholového zámku, tak je samozřejmostí, že jeho instalace by měla být ukládána za porušení pravidel silničního provozu řidičem motorového vozidla pouze v souvislosti s požitím alkoholu ${ }^{30}$. Jednoznačná naopak není otázka, jak je zřejmé z příkladů legislativy některých evropských zemí, v rámci kterého právního odvětví má být alcolock ukládán (zda v rámci správního práva nebo trestního práva). Zatímco $\mathrm{v}$ některých zemích je alkoholový zámek začleněn do správního práva (např. Švédsko a Nizozemí), jinde je naopak součástí trestního práva (např. Polsko). Nelze jednoznačně konstatovat, která varianta je

${ }^{27}$ EU urged to roll out car breathalyser 'alcolocks' stopping drink drivers to cut alcohol-related deaths. Independent [online], 13. 2. 2017, [cit. 10. 3. 2017]. Dostupné z: http://www.independent.co.uk/news/world/europe/eu-car-breathalyser-alcolocks-drinkdriver-deaths-alcohol-accidents-european-parliament-union-a7578351.html

28 1) legislativní zakotvení; 2) technické aspekty (včetně ochrany osobních údajů); 3) rehabilitační aspekty; 4) vynutitelnost; 5) náklady na program; 6) testování a vyhodnocování programu; 7) komunikace s veřejností. Viz HOUWING, Sjoerd. Alcohol Interlocks and Drink Driving Rehabilitation in the European Union. ETSC [online]. 2016, [cit. 12. 7. 2017], s. 6-7. Dostupné z: http://etsc.eu/alcohol-interlocks-and-drink-driving-rehabilitation-in-the-euguidelines-for-member-states/

29 Všechny uváděné zahraniční př́iklady v následujících podkapitolách, pokud není uvedeno jinak, vychází z materiálu HOUWING, Sjoerd. Alcohol Interlocks and Drink Driving Rehabilitation in the European Union. ETSC [online]. 2016, s. 13-28, [cit. 22. 5. 2017].

${ }^{30}$ Včetně případu odmítnutí řidiče podrobit se vyšetření na ovlivnění alkoholem. 
vhodnější, konkrétní volba by se měla opírat o specifickou povahu obou odvětví v dané zemi a o zamýšlený úmysl zákonodárce při zavedení alcolocku, nicméně nedůsledné vyřešení této otázky může vést $\mathrm{k}$ aplikačním problémům, které budu blíže demonstrovat na příkladu z Nizozemí.

Jak bylo řečeno, v Nizozemí je alcolock součástí správního práva. Od prosince roku 2011 tamní správní orgán (dále „CBR“) 31 řidičům, kteří tzv. nadýchali, obligatorně ukládal opatření, jehož podoba závisela na konkrétní zjištěné hladině alkoholu u pachatele (od nejnižší hladiny alkoholu po nejvyšší byl pachateli uložen bud' program na polepšení řidiče ${ }^{32}$; nebo alcolock; nebo psychiatrické vyšetření na závislost, po kterém může následovat uložení alcolocku, $\mathrm{v}$ prrípadě zjištění, že pachatel závislostí netrpí). Při uložení alcolocku pachatel podal žádost o nový řidičský průkaz pro skupinu vozidel typu B se speciálním kódem, přičemž jeho případné řidičské oprávnění ve vztahu $\mathrm{k}$ ostatním skupinám vozidel bylo zneplatněno (s výjimkou vozidel skupiny AM). Program trval minimálně 2 roky, náklady programu hradil řidič a každých 46 dní byl povinen předat data, která CBR dále analyzuje, zčehož mohly být vyvozeny další právní důsledky (prodloužení programu, benefit delší lhůty pro předání dat, apod.). Zárodkem problému byla skutečnost, že nezávisle na uložení tohoto programu mohlo být proti stejnému pachateli vedeno také trestní stíhání, které mohlo vyústit v trest ${ }^{33}$ uložený nizozemským trestním soudem. ${ }^{34}$

31 Jedná se o Ústřední úřad pro způsobilost řidičů (Centraal Bureau Rijvaardigheidsbewijzen), který je pověřen posuzováním odborné a zdravotní způsobilosti řidičů. Viz De organisatie. CBR [online]. [cit. 20. 11. 2017]. Dostupné z: https://cbr.nl/organisatie.pp

32 „Driver improvement program.“

${ }^{33} \mathrm{~V}$ závislosti na konkrétní hladině alkoholu bud’ samostatnou pokutu, nebo pokutu ve spojení se zákazem činnosti.

${ }^{34}$ Prezentace z odborného semináře. SCHAAP, Desirée. Dutch Alcohol Interlock Program. Ministerie van Verkeer en Waterstaat. [online], 10. 5. 2012 [cit. 4. 7. 2017]. Dostupné z: https://www.cdv.cz/file/prezentace-bezpecna-a-strizliva-doprava-ministry-of-infrastructure -and-the-environment/

Ve spojení s rozhodnutím nizozemského Nejvyššího soudu ze dne 3. 3. 2015, sp. zn. 14/04940. Dostupné z: http://deeplink.rechtspraak.nl/uitspraak?id=ECLI:NL:HR: 2015:434 
Nizozemský Nejvyšší soud (Hoge Raad der Nederlanden - v našich podmínkách by se jednalo o Nejvyšší soud) ${ }^{35} \mathrm{v}$ souvislosti s tímto případem zvažoval otázku, zda uložení alcolocku má důsledky pro trestní stíhání pachatele za stejný skutek a dospěl k závěru, že v těchto případech trestní stíhání porušuje spravedlivý proces (konkrétně zákaz dvojího stíhání/trestání za stejný skutek). Nejvyšší soud proto zamítl dovolání a potvrdil správnost závěru rozhodnutí odvolacího soudu o nepřípustnosti trestního stíhání. Ve vztahu k povaze alcolocku je zajímavá i argumentace odvolacího soudu, který se rozsáhleji věnoval otázce, proč ho lze podřadit pod pojem „trestního obvinění" ve smyslu čl. 6 odst. 1 Evropské úmluvy o ochraně lidských práv. Odvolací soud pro tyto účely standardně využil tzv. Engelova kritéria a za pozornost stojí zejména analýza povahy a závažnosti alcolocku (třetí kritérium), v rámci které odvolací soud vzájemně zvažoval zejména tyto důvody:

- program má zásadní dopad na řidičské oprávnění nebo na majetkovou sféru

- program pachateli nenabízí žádnou rozumnou volbu - bud' se účastní alcolocku nebo se podrobí automatickému zákazu činnosti na 5 let (přičemž tento zákaz může mít dalekosáhlé důsledky)

- náklady programu, které hradí pachatel, jsou velmi vysoké (4 tis. 5 tis. euro)

- $\quad$ program se ukládá za první delikt (nemírí pouze na nepoučitelné řidiče)

- odvolání postrádá suspenzivní účinek

- absence jakékoliv diskreční pravomoci (individualizace) pro (ne)uložení programu

Tento případ poukazuje na možná úskalí vzájemného vztahu alcolocku a systému veřejnoprávního trestání, která by měl mít na vědomí i český zákonodárce při implementaci programu. Nizozemský Nejvyšší soud tamního zákonodárce výslovně pokáral za to, že ponechal vztah mezi uložením alcolocku a trestním stíháním bez výslovné úpravy, která by poskytovala vodít-

35 Rozhodnutí nizozemského Nejvyššího soudu ze dne 3. 3. 2015, sp. zn. 14/04940. Dostupné z: http://deeplink.rechtspraak.nl/uitspraak?id=ECLI:NL:HR:2015:434 
ko, jakým způsobem se trestní soudce $s$ touto skutečností může vypořádat (při úvahách procesních a hmotněprávních), což by s ohledem na judikaturu Evropského soudu pro lidská práva ${ }^{36}$ mohlo mít relevanci pro právní závěr př́padu.

Sám o sobě podle mě „zákaz řídit pod vlivem alkoholu“ (alcolock) žádnou sankci nepředstavuje, a proto je třeba věnovat pozornost kritériím jeho „tvrdosti“, která zdůrazňuje odvolací soud a jejichž konkrétní nastavení může dle mého názoru povahu opatření alcolocku jako „trestu“, nebo jako „netrestního opatření“ výrazně ovlivnit.

\subsection{OBLIGATORNÍ OPATŘENÍ, NEBO DOBROVOLNÝ ZÁVAZEK (VČETNĚ DOBY TRVÁNÍ)}

Samotný charakter vzniku povinnosti účastnit se programu je v evropských státech rovněž odlišný - bud’ je uložena obligatorně, nebo funguje na bázi dobrovolnosti. Zároveň se liší podmínky, za kterých může tato povinnost vzniknout, a posuzované země také různě pracují s délkou programu.

Například ve zmiňovaném Nizozemí mají pro obligatorní uložení alcolocku mírnější hladinu alkoholu pro skupinu prvopachatelů $(1,3-1,8$ \%; vyšší hladina vede $k$ posouzení závislosti), přísnější pro skupinu nových řidičů (1\%0) a nejpř́śšjěší pro recidivující řidiče $(0,8 \% 0)$. Program zde standardně trvá 2 roky a může být prodlužován $\mathrm{v}$ závislosti na pokusech účastníka nastartovat vozidlo pod vlivem alkoholu. Dobrovolný charakter má opatření například ve Finsku (zde program může trvat 12 - 36 měsíců) a ve Švédsku (zde pro stanovení konkrétní délky trvání programu využívají zjištěnou hladinu alkoholu ${ }^{37}$ ). V Polsku je alcolock také dobrovolnou možností a vztahuje se na řidiče s hladinou alkoholu nad $0,5 \%$, nicméně

\footnotetext{
${ }^{36}$ Nilsson proti Švédsku, rozhodnutí senátu ESLP ze dne 13. 12. 2005, stížnost č. 73661/01, Nykänen proti Finsku, rozsudek senátu ESLP ze dne 20. 5. 2014, stížnost č. 11828/11. $\mathrm{Z}$ doby po citovaném rozhodnutí nizozemského Nejvyššího soudu lze zmínit $A$. B. proti Norsku, rozsudek velkého senátu ESLP ze dne 15. 11. 2016, stížnosti č. 24130/11 a 29758/11. Judikatura vyžaduje dostatečnou vzájemnou provázanost obou řízení o „trestu“.

37 Vizte také SKARVIKEN, Pär-Ola. The Swedish Alcohol Interlock Program for offenders [online]. 17. 10. 2017, [cit. 20. 11. 2017]. Dostupné z: http://etsc.eu/wp-content/uploads/TheSwedish-Alcohol-Interlock-Program-for-offenders.pdf
} 
pachatel musí nejprve vykonat určitou část sankce zákazu činnosti a teprve po jejím výkonu se může zúčastnit programu alkoholového zámku, jehož délka je určena podle zbývající doby původního zákazu činnosti. Obdobné provedení mají i v Rakousku ${ }^{38}$, nicméně délka programu je tam určena jako dvojnásobek zbývající doby původního zákazu činnosti s minimální délkou šest měsíců.

\subsection{NÁKLADY ZA ÚČAST V PROGRAMU}

Náklady za účast v programu povětšinou zahrnují instalaci/odinstalaci zařízení, vydání nového řidičského průkazu, kontrolu dat z alcolocku, kalibraci zařízení atd. Zejména kontroly zachycených dat jsou klíčovou položkou, jelikož úprava četnosti jejich provádění může na jednu stranu výši nákladů výrazně ovlivnit, na druhou stranu tato úprava bude mít prímý dopad na efektivitu alcolocku jako preventivního nástroje proti řízení pod vlivem alkoholu.

V zásadě ve všech zemích (např. Nizozemí, Polsko, Finsko, Švédsko) jsou tyto náklady povinně hrazeny samotným účastníkem a navíc se často jedná o výraznou částku (cca 110 - 200 euro za měsíc), což samozřejmě snižuje obecnou popularitu tohoto opatření a zvyšuje jeho „tvrdost“. Proto $\mathrm{v}$ některých zemích (např. Finsko, Švédsko) přistoupili $\mathrm{k}$ postupnému „okrajování“ programu za účelem snížení nákladů na rozumnou míru, aby došlo ke zvýšení účasti $\mathrm{v}$ programu. $\mathrm{V}$ takovém případě se samozřejmě nelze vyhnout zmiňovanému riziku snižování efektivity (menší počet či případná absence pravidelných kontrol evidovaných dat apod.). Další možností snížení nákladů může být existence soutěže mezi více dodavateli alcolocků (v některých státech USA a v Austrálii dodavatelé nabízí např. možnosti slev pro lidi $v$ hmotné nouzi ${ }^{39}$ ).

Právní úskalí spojená s otázkou hrazení nákladů za účast v programu budu demonstrovat na rozhodnutí, které bylo $\mathrm{v}$ této souvislosti vydáno

${ }^{38}$ KALTENEGGER, Armin. Alternative probation system (APS) in Austria [online]. KFV Austrian Road Safety Board, 17. 10. 2017, [cit. 20. 11. 2017]. Dostupné z: http://etsc.eu/wpcontent/uploads/KALTENEGGER_ABS_EN_ETSC_Bern.pdf

39 HOUWING, Sjoerd. Alcohol Interlocks and Drink Driving Rehabilitation in the European Union. ETSC [online]. 2016, s. 7, [cit. 22. 5. 2017]. 
(opět) v Nizozemí. Tamní správněprávní kolegium Rady státu (Afdeling Bestuursrechtspraak van de Raad van State, dále jen „Rada státu“ - v našich podmínkách by se jednalo o Nejvyšší správní soud ${ }^{40}$ posuzovalo případ automechanika, kterému byla naměřena spodní hranice hladiny alkoholu pro uložení alcolocku. V podaném opravném prostředku argumentoval existencí neproporcionálního zásahu do svého života, jelikož správní orgán nemohl vzít v potaz specifické okolnosti př́padu (spodní hranice hladiny alkoholu, zkoušení pojízdnosti aut je součástí výkonu jeho práce).

Rada státu ve svém rozhodnutí v první řadě zdůraznila, že alcolock má potenciál naplnit úmysl zákonodárce, kterým bylo snížení fatálních následků nehod spojených s alkoholem, a to včetně výchovného efektu - naučit pachatele oddělovat konzumaci alkoholu od rrízení vozidla. Poukázala ovšem na paradox, že z důvodu vysokých nákladů programu (které byly v praxi dokonce vyšší, než předpokládal zákonodárce) není výchovného účelu dosahováno, jelikož mnoho pachatelů se obligatorně uloženého opatření nemůže $\mathrm{z}$ finančních důvodů účastnit. $\mathrm{V}$ důsledku toho se musí podrobit pětiletému zákazu činnosti, který má z povahy věci ještě dalekosáhlejší „represivní“ důsledky, které mohou být neúměrné (např. pokud je účastník nadprůměrně závislý na užívání vozidla - Rada státu uvádí příklad snížené mobility členů rodiny). Rozhodnutí je uzavřeno tím, že absence jakékoliv možnosti individualizace při ukládání alcolocku nezaručuje dostatečně proporcionalitu opatření a způsobuje neaplikovatelnost předmětné právní normy. Po tomto rozhodnutí došlo $\mathrm{k}$ definitivnímu zrušení programu alkoholového zámku v Nizozemí, nicméně jsou zvažovány varianty pro jeho znovuzavedení, které by reagovaly na kritiku vyslovenou soudy ${ }^{41}$.

Uvedené argumenty v zásadě obsahově navazují na dříve citované rozhodnutí nizozemského Nejvyššího soudu ${ }^{42}$ a je třeba je vnímat v kontextu

\footnotetext{
40 Rozhodnutí nizozemského správněprávního kolegia Rady státu ze dne 4. 3. 2015, sp. zn. 201400944/1/A1. Dostupné z: https://www.raadvanstate.nl/uitspraken/zoeken-in-uitspraken/tekst-uitspraak.html?id $=82862$

${ }^{41}$ Srov. také Dutch Alcohol Policy. STAP - Dutch Institute for Alcohol Policy [online]. [cit. 20. 11. 2017]. Dostupné z: http://www.stap.nl/en/home/dutch-alcohol-policy.html

${ }^{42}$ Rozhodnutí Správní rady bylo vydáno o den později než rozhodnutí nizozemského Nejvyššího soudu a v rámci odůvodnění je na něj odkazováno.
} 
„represivní“ povahy alcolocku v Nizozemín ${ }^{43}$. Rozhodnutí poukazuje na dva možné negativní právní důsledky nákladů za účast $\mathrm{v}$ programu: jednak může dojít $\mathrm{k}$ vyloučení množství potenciálních účastníků (rozpor s legitimním účelem programu) a jednak mohou způsobovat nepřiměřenost opatření (rozpor s principem proporcionality).

\section{4. ÚVAHY DE LEGE FERENDA}

$\mathrm{V}$ rámci této kapitoly uvádím $\mathrm{k}$ výše zmiňovaným oblastem nastavení programu alkoholového zámku úvahy o možném vhodném nastavení v podmínkách České republiky, které mohou posloužit jako podněty $\mathrm{k}$ další diskuzi o tomto institutu. Tyto úvahy vyplývají zejména ze syntézy předchozí komparativní části, účelu alcolocku a názoru autora článku.

\subsection{SOUČÁST SPRÁVNÍHO NEBO TRESTNÍHO PRÁVA ANEB RIZIKO DVOJÍHO TRESTÁNÍ}

Domnívám se, že pro Českou republiku by nebylo vhodné začlenit alcolock bud' pouze do roviny správního práva, nebo pouze trestního práva. Naše judikatura stanovila obecnou hranici hladiny alkoholu pro posouzení, jestli je způsobilost řidiče řídit motorové vozidlo ovlivněna (nižší hladina $=$ přestupek) nebo vyloučena (vyšší hladina $=$ trestný čin ${ }^{44}$ ) na hodnotu $1 \%{ }^{45}$. Výlučné začlenění alkoholového zámku do jednoho z „trestních“ systémů by tak mohlo být zbytečně limitující, proto by bylo vhodné umožnit jeho ukládání v rámci obou. Tímto př́stupem by také zřejmě bylo minimalizováno riziko pro úvahy o př́ípadném porušení zákazu dvojího trestání, jako tomu bylo v prvně uváděném příkladu z Nizozemí.

${ }^{43}$ Například se domnívám, že absence procesu individualizace je více problematická, pokud má opatření sankční povahu.

${ }^{44}$ I zákon o silničním provozu v $§ 125$ odst. 1 písm. c) obsahuje skutkovou podstatu přestupku - ř́zení ve stavu „vylučujícím způsobilost“. Tato skutková podstata se ovšem vzhledem ke společenské škodlivosti jednání pravděpodobně neuplatní u řidičů motorových vozidel, ale pouze u řidičủ vozidel nemotorových. Viz. KUČEROVÁ, Helena. Zákon o silničním provozu s komentáŕem a judikaturou. 3. akt. vyd. Praha: Leges, 2016, s. 686.

45 Např. usnesení Nejvyššího soudu ze dne 22. 8. 2007, sp. zn. 5 Tdo 874/2007, uveřejněné pod č. 26/2008 Sbírky soudních rozhodnutí a stanovisek. 
Při volbě varianty zakotvení alcolocku pouze do jednoho z právních odvětví by bylo vhodné $\mathrm{v}$ kontextu zmiňované judikatury výslovně vyřešit vzájemný vztah k druhému právnímu odvětví.

\subsection{OBLIGATORNÍ OPATŘENÍ, NEBO DOBROVOLNÝ ZÁVAZEK (VČETNĚ DOBY TRVÁNÍ)}

Stran obligatorního nebo dobrovolného charakteru se domnívám, že smyslu a účelu alkoholového zámku nejlépe odpovídá princip dobrovolnosti, čemuž v zásadě odpovídá i úprava ve většině zemí. Zavedení alcolocku na základě tohoto principu podle mě maximálně posílí jeho zamýšlený výchovný účinek - pokud si sám pachatel některou variantu (alcolock) zvolí, lze vycházet z vyšší míry jeho ztotožnění s touto variantou a z jeho vnitřní snahy o osvojení si nových návyků. Domnívám se také, že právě důraz na dobrovolný charakter programu rozvolní sankční povahu alkoholového zámku a touto cestou je tak možné vyvarovat se obdobným problémům, které se vyskytly v Nizozemí.

Jelikož jsou za současné legislativní „nulové tolerance“ v České republice pokuta a zákaz činnosti ukládány za řízení motorového vozidla s jakoukoliv hladinou alkoholu ${ }^{46}$, tak by se mi jako možná vhodná varianta jevila ta, kdy by do určité hladiny ${ }^{47}$ byl alkoholový zámek nabízen jako typ „odklonu“ k uložení zákazu činnosti a nad tuto hranici by se jednalo o fakultativní možnost přeměny sankce ${ }^{48}$. Tato konstrukce by dle mého měla reflektovat (ne)přítomnost strategického rozhodnutí řidiče řídit pod vlivem alkoholu a zároveň zdůrazňovat výchovný potenciál alcolocku. Za méně společensky závažné porušení (pochybení) by bylo možné pachateli na-

\footnotetext{
${ }^{46} \S 125$ c odst. 5 písm. a), c); odst. 6 a), c) zákona o silničním provozu. Ve spojení s rozsudkem Nejvyššího správního soudu ze dne 21. 9. 2010, čj. 8 As 59/2010-78, publikováno pod č. 2168/2011 Sbírky rozhodnutí Nejvyššího správního soudu.

47 Přičemž se domnívám, že pro zkušené řidiče by se mělo uplatnit stejné měřítko přísnosti (hranice hladiny alkoholu) jako pro nové řidiče. Z hlediska prevence proti řízení pod vlivem alkoholu nevnímám diferenciaci mezi zkušenými a nezkušenými řidiči jako vhodnou.

48 Domnívám se, že i v př́ípadě uložení alcolocku by měla být zachována povinnost absolvovat následně dopravně psychologické vyšetření , obdobně jako by byl uložen zákaz činnosti. Vizte § 87a odst. 3 zákona o silničním provozu.
} 
bídnout rozumnou volbu mezi sankčním pozbytím řidičského oprávnění a jeho výchovným omezením za stanovených podmínek, právě s odůvodněním, že u této hranice alkoholu se nemusí jednat o strategické rozhodnutí řidiče. Naopak u vyšší hranice alkoholu je třeba př́tomnost společensky závažného strategického rozhodnutí řidiče doprovodit i opatřením represivního charakteru. Nad touto hranicí bych vnímal jako nutné vykonat nejprve část zákazu činnosti (represe ve vztahu ke strategickému rozhodnutí) a až po jejím výkonu by bylo možné na základě vůle pachatele přeměnit sankci na uložení alcolocku (možnost zmírnění opatření za účelem převýchovy ve vztahu k budoucímu strategickému rozhodování řidiče).

Specifickou společensky nebezpečnou skupinu tvoří recidivující pachatelé, jelikož vykazují určitou míru „nevychovatelnosti“. Z toho důvodu se mi jeví jako opodstatněné a přiměřené uplatňovat $v$ jejich případě částečně odlišný postup. Bez ohledu na konkrétní hladinu alkoholu by vzhledem ke specifickému charakteru recidivistů následovalo vždy represivní opatření (zákaz činnosti), které reaguje na opakovanost pochybení/strategického rozhodnutí. $\mathrm{V}$ závislosti na konkrétní hladině alkoholu (která by mohla být stanovena př́ísněji, než u výše uvedených prvopachatelů) by se ovšem lišil následující postup - opět v souvislosti s usuzovanou (ne)prítomností strategického rozhodnutí řidiče. $\mathrm{V}$ případě, že pachatel jeví známky vychovatelnosti (ve vztahu k aktuálnímu rrízení pod vlivem alkoholu je možná absence jeho strategického rozhodnutí), byla by mu po výkonu určité části zákazu činnosti opět umožněna přeměna sankce na alcolock. $V$ př́ípadě, že se jedná o pachatele, který opakovaně činí strategické rozhodnutí řídit pod vlivem alkoholu, měla by po výkonu (celého) zákazu činnosti následovat obligatorní instalace alkoholového zámku - pachatel totiž patří do společensky nejzávažnější skupiny opilých řidičů a je vhodné ho podrobit důkladnějšímu pozvolnému výchovnému procesu, který bude kontrolován. V závislosti na to, jakým způsobem bude vyhodnocována jeho účast v programu alkoholového zámku, by mělo být možné bud' zrušit omezení řidičského oprávnění, nebo ho naopak zcela odejmout.

Domnívám se, že výše nastíněné schéma by mohlo být jednou z možných variant, které respektují a podporují hlavní účel alcolocku, kte- 
rým je zejména převýchova a případné ultima ratio postavení nebezpečných účastníků mimo silniční provoz.

Otázkou je konkrétní hranice alkoholu, která by byla dle výše naznačeného schématu „hraniční“ zejména z hlediska možné absence strategického rozhodnutí řidiče (resp. byla by významná z hlediska rozlišení nedbalosti a úmyslu). Ačkoliv se jedná o otázku, kterou si netroufám posuzovat, je jistě možné za určité vodítko považovat úpravy evropských zemí, které ve většině tolerují za volantem hladinu alkoholu do $0,5 \%{ }^{49}$, což podle mě vyjadřuje skutečnost, že (minimálně) zákonodárce předpokládá, že př̀i této hladině je vliv alkoholu na řízení neznatelný. Zároveň by při určování konkrétních hodnot mohly být využity citované statistiky Policie ČR, jelikož alkoholový zámek by měl přispět $\mathrm{k}$ k potlačení zejména společensky nejzávažnější kategorie opilých řidičů a tyto statistiky dopravní nehody a následky rozlišují i podle výše zjištěné hladiny alkoholu u pachatele.

Stran konkrétní délky trvání programu se domnívám, že je vhodné zakotvit motivačně-výchovnou možnost následného přizpůsobení podle výsledků vyhodnocování dat - konkrétní právní skutečnosti mohou způsobovat prodloužení nebo zkrácení programu ${ }^{50}$ a je třeba myslet i na možnost předčasného ukončení programu a to jak nedobrovolného, tak dobrovolného. V této souvislosti je možné zvážit i vytvoření nových skutkových podstat (přestupkových/trestních), které budou chránit zájem na řádném fungování programu alkoholového zámku, příp. možnost využití stávajících.

\subsection{NÁKLADY ZA ÚČAST V PROGRAMU}

Stran otázky nákladů se domnívám, že s ohledem na účel programu není vhodné jejich výši držet na co možná nejnižší úrovni na úkor efektivity alkoholového zámku. Na př́kladu z Finska, kde od konce roku 2016 za úče-

\footnotetext{
49 Blood Alcohol Content (BAC) Drink Driving Limits across Europe. ETSC [online], naposledy akt. v červnu 2016, [cit. 20. 11. 2017]. Dostupné z: http://etsc.eu/blood-alcohol-contentbac-drink-driving-limits-across-europe/

${ }^{50}$ HOUWING, Sjoerd. Alcohol Interlocks and Drink Driving Rehabilitation in the European Union. ETSC [online]. 2016, [cit. 20. 11. 2017], s. 25-26. Dostupné z: http://etsc.eu/alcohol-interlocks-and-drink-driving-rehabilitation-in-the-eu-guidelines-for-member-states/
} 
lem snížení nákladů upustili od povinnosti odesílat data, která alcolock uchovává, je vidět dvousečnost takového opatření. Sice došlo ke snížení nákladů, nicméně monitorování účastníku programu se stalo prakticky nemožným ${ }^{51}$, což výrazně omezuje možnost přizpůsobení délky trvání „na míru“ konkrétnímu účastníkovi a celkově tím opatření ztrácí preventivněvýchovný efekt.

Otázka nákladů nabývá obzvláště na významu v případě alcolocku jako obligatorního opatření, jak vyplývá z nizozemských rozhodnutí v této věci. Největším problémem tamního programu alkoholového zámku byla absence procesu individualizace $\mathrm{v}$ kombinaci s obligatorním charakterem ukládání. Pachatelům, kteří se obligatorně uloženého alcolocku nemohli z finančních důvodů účastnit, byla navíc uložena alternativa v podobě předem určeného pětiletého zákazu činnosti. Princip individualizace sankce (a jeho personalizace) by tedy měl být zachován - v zásadě se domnívám, že náklady za účast $\mathrm{v}$ uloženém programu by měly být vnímány jako součást „represivního“ finančního opatření, které je pachateli za jízdu pod vlivem alkoholu ukládáno, tedy jako součást finanční pokuty. Pokud by účastník měl vstoupit do programu alcolocku, odůvodnění výše souběžně ukládané pokuty by mělo reflektovat předvídatelné náklady, které bude v souvislosti s alkoholovým zámkem (dobrovolným/obligatorním) povinen platit.

Za vhodnou variantu bych tedy považoval legislativní úpravu respektující dílčí účel existence alcolocku, kterým by mělo být umožnění rozumné volby pachateli mezi tím, jestli se podrobí zákazu činnosti nebo omezení řidičského oprávnění ve spojení s určitým finančním zatížením. Toto zatîžení by nemělo být extrémní, aby ve svém důsledku nezpůsobovalo exkluzivitu opatření pouze pro určitou skupinu pachatelů. Zároveň by právní úprava měla garantovat, že nebude docházet $\mathrm{k}$ neproporcionálním zásahům. Domnívám se tedy, že $\mathrm{v}$ případě, že náklady na program nebude možné více snízit bez následku v podobě eliminace efektivity, měla by existovat možnost maximálního přizpůsobení úhrady nákladů poměrům konkrétního

51 HOUWING, Sjoerd. Alcohol Interlocks and Drink Driving Rehabilitation in the European Union. ETSC [online]. 2016, [cit. 12. 7. 2017], s. 17. Dostupné z: http://etsc.eu/alcohol-interlocks-and-drink-driving-rehabilitation-in-the-eu-guidelines-for-member-states/ 
účastníka, aby byla zajištěna rozumná volba a garance přiměřenosti co nejširšímu okruhu subjektů (např. může pro odůvodněné případy existovat možnost částečné úhrady nákladů státem).

\section{ZÁVĚR}

Při snaze o snižování závažných následků dopravních nehod směrem $\mathrm{k}$ Vizi Nula je třeba pracovat se systémem silničního provozu jako komplexním celkem, který je tvořen vozidlem, infrastrukturou a lidským faktorem. Nehody způsobené vlivem alkoholu jsou typickým př́kladem situace, kde selhává primárně lidský faktor (již na strategické úrovni rozhodování), na který je proto třeba vhodným způsobem působit.

Dosavadní právní metody působení na lidský faktor, které představuje zejména hrozba a uplatnění sankce zákazu činnosti, u některých skupin řidičů (zejména u těch společensky nejzávažnějších - recidivistů) nepřináší zamýšlený účinek. Alkoholový zámek je př́kladem komplexního vnímání, ze své podstaty je to opatření, které je součástí vozidla a slouží $\mathrm{k}$ působení na lidský faktor a jeho výchově. Právě silnější důraz alcolocku v převýchově řidiče na úrovni jeho strategického rozhodování, zda řídit pod vlivem alkoholu, nebo nikoliv, je $\mathrm{v}$ porovnání se zákazem činnosti jeho největší devizou.

V článku jsem se snažil o základní představení programu alkoholového zámku na základě jeho úpravy v některých evropských zemích. Vzhledem k tomu, že Národní strategie bezpečnosti silničního provozu stanoví jeho postupné zavádění i v České republice, domnívám se, že je vhodné na existenci tohoto opatření a související právní problematiku upozornit i českou odbornou veřejnost.

Právní problematiku, která se tohoto institutu dotýká, tento článek ovšem nevyčerpává, pouze upozorňuje na některá klíčová místa, kterým by měla být věnována zvýšená pozornost (zejména na základě příkladů ze zahraničí). $\mathrm{V}$ praxi bude implementace programu alkoholového zámku do českého právního řádu otázkou mnohem komplexnější, která si bude žádat řešení i mnohých dalších souvisejících otázek (ochrana osobních údajů; souvislost s rehabilitačním programem; apod.). Nástin úpravy programu, 
který uvádím v sekci de lege ferenda, vychází z obecné myšlenky maximálního využití výchovného potenciálu, kterým alcolock disponuje. Jako takové tyto úvahy mohou posloužit $\mathrm{k}$ diskuzi nad konkrétním provedením „chystaného“ opatření v České republice.

\section{DEDIKACE:}

Tento článek byl vytvořen za finanční podpory Ministerstva školství, mládeže a tělovýchovy $v$ rámci programu Národní program udržitelnosti I, projektu Dopravní VaV centrum (LO1610) na výzkumné infrastruktuře pořizené z Operačního programu Výzkum a vývoj pro inovace (CZ.1.05/2.1.00/03.0064).

\section{SEZNAM ZDROJŮ}

\subsection{MONOGRAFIE, ODBORNÉ ČLÁNKY, KONCEPČNÍ MATERIÁLY, PREZENTACE, TABULKY, STATISTIKY, AKTUALITY, VIDEA}

[1] BELIN, Matts-Ake a kol. The Vision Zero and its Consequences [online]. 1997. 13 s. Dostupné z: http://www.trafikverket.se/contentassets/5e3d8c0eb4e94efd9738cca74b912bf5/ vz_and_its_consequenses.pdf

[2] Blood Alcohol Content (BAC) Drink Driving Limits across Europe. ETSC [online], naposledy akt. v červnu 2016. Dostupné z: http://etsc.eu/blood-alcohol-content-bac-drink-drivinglimits-across-europe/

[3] COWI, SWOV, ADV. Study on the Prevention of Drink-Driving by the use of alcohol interlock devices [online]. 2014, 164 s. Dostupné zde: https://ec.europa.eu/transport/ road_safety/sites/roadsafety/files/newspdf/study_alcohol_interlock.pdf

[4] Dutch Alcohol Policy. STAP - Dutch Institute for Alcohol Policy [online]. Dostupné z: http://www.stap.nl/en/home/dutch-alcohol-policy.html

[5] ELDER, Randy W. e al. Effectiveness of Ignition Interlocks for Preventing Alcohol-Impaired Driving and Alcohol-Related Crashes [online]. 2011, 362-376. Dostupné online z: https://www.thecommunityguide.org/sites/default/files/assets/PIIS07493797100071051.pdf

[6] EU urged to roll out car breathalyser 'alcolocks' stopping drink drivers to cut alcohol-related deaths. Independent [online], 13. 2. 2017. Dostupné z: http://www.independent.co.uk/news/world/europe/eu-car-breathalyser-alcolocks-drinkdriver-deaths-alcohol-accidents-european-parliament-union-a7578351.html

[7] Eurobarometr - EU citizens' attitudes towards alcohol. European Comission [online], 2010. 74 s. Dostupné zde: http://ec.europa.eu/health//sites/health/files/alcohol/ docs/ebs_331_en.pdf 
[8] FAQ. Lifesaver [online]. 2017. Dostupné z: https://www.lifesafer.com/support/frequentlyasked-questions/

[9] HOUWING, Sjoerd. Alcohol Interlocks and Drink Driving Rehabilitation in the European Union. ETSC [online]. 2016, 35 s. Dostupné z: http://etsc.eu/alcohol-interlocks-and-drinkdriving-rehabilitation-in-the-eu-guidelines-for-member-states/

[10] KALTENEGGER, Armin. Alternative probation system (APS) in Austria [online]. KFV Austrian Road Safety Board, 17. 10. 2017. Dostupné z: http://etsc.eu/wpcontent/uploads/KALTENEGGER_ABS_EN_ETSC_Bern.pdf

[11] KUČEROVÁ, Helena. Zákon o silničním provozu s komentářem a judikaturou. 3. akt. vyd. Praha: Leges, 2016, 826 s. ISBN 978-80-7502-105-2.

[12] MICHON, John A. A critical view of driver behavior models: What do we know? What should we do? In. L. Evans et al. (eds.). Human Behavior and Traffic Safety. Plenum Press, New York, 1985, s. 485-524. ISBN 978-1-4612-9280-7. Dostupné i online z: http://jamichon.nl/jam_writings/1985_criticial_view.pdf

[13] MIKULÍK, Josef a kol. Bezpečnost silničního provozu - aktuální poznatky. I. díl, Centrum dopravního výzkumu, v. v. i., 2011, 196 s. ISBN 978-80-86502-35-9.

[14] Národní strategie bezpečnosti silničního provozu 2011 - 2020. Ministerstvo dopravy, samostatné oddělení BESIP [online], 77 s. Dostupné z: http://www.ibesip.cz/data/web/soubory/nsbsp-2011-2020-formatovani-ii.pdf

[15] Policie si v Jihomoravském kraji došlápla na řidiče autobusů, chytla šest opilých. Novinky.cz [online], 23. 1. 2017. Dostupné z: https://www.novinky.cz/krimi/427224-policiesi-v-jihomoravskem-kraji-doslapla-na-ridice-autobusu-chytila-sest-opilych.html

[16] Revize a aktualizace Národní strategie bezpečnosti silničního provozu $2011-2020$, s platností od roku 2017. Ministerstvo dopravy, samostatné oddělení BESIP [online], $112 \mathrm{~s}$.

[17] Rien bu! Merci BOB. Youtube [online]. Publikováno 2. 12. 2016. Dostupné z: https://www.youtube.com/watch?v = J-Bli-P0S1k

[18] Road Safety: Encouraging results in 2016 call for continued efforts to save lives on EU roads. European Commission - Press Release [online]. 28. 3. 2017. Dostupné z: http://europa.eu/rapid/press-release_IP-17-674_en.htm

[19] SCHAAP, Desirée. Dutch Alcohol Interlock Program. Ministerie van Verkeer en Waterstaat. [online], 10. 5. 2012. Dostupné z: https://www.cdv.cz/file/prezentace-bezpecna-a-strizlivadoprava-ministry-of-infrastructure-and-the-environment/

[20] SKARVIKEN, Pär-Ola. The Swedish Alcohol Interlock Program for offenders [online]. 17. 10. 2017. Dostupné z: http://etsc.eu/wp-content/uploads/The-Swedish-Alcohol-InterlockProgram-for-offenders.pdf

[21] Statistika nehodovosti. Policie České republiky [online]. [cit. 23. 5. 2017]. Dostupné z: http://www.policie.cz/clanek/statistika-nehodovosti-900835.aspx?q=Y2hudW09Mg\%3d\%3d 


\subsection{ZÁKONY, VYHLÁŠKY, USNESENÍ, SMĚRNICE EVROPSKÉ UNIE}

[22] Směrnice Evropského parlamentu a Rady 2006/126/ES ze dne 20. prosince 2006 o řidičských průkazech (přepracované znění). In: EUR-Lex. Dostupné z: http://eurlex.europa.eu/legal-content/CS/ALL/?uri = CELEX:02006L0126-20150515

[23] Usnesení vlády č. 160 ze dne 27. 2. 2017 o Revizi a aktualizaci Národní strategie bezpečnosti silničního provozu na období let 2011 až 2020 s platností od roku 2017. In: Aplikace o/dok. Dostupné z: https://apps.odok.cz/attachment/-/down/RCIAAK4B536X

[24] Vyhláška č. 327/1951 Ú.I.I, kterou se stanoví pravidla silničního provozu.

[25] Zákon č. 81/1935 Sb. z. a n., o jízdě motorovými vozidly.

[26] Zákon č. 361/2000 Sb., o provozu na pozemních komunikacích a o změnách některých zákonů (zákon o silničním provozu).

\subsection{JUDIKATURA}

[27] A. B. proti Norsku, rozsudek velkého senátu ESLP ze dne 15. 11. 2016, stížnosti č. $24130 / 11$ a $29758 / 11$.

[28] Nilsson proti Švédsku, rozhodnutí senátu ESLP ze dne 13. 12. 2005, stížnost č. 73661/01.

[29] Nykänen proti Finsku, rozsudek senátu ESLP ze dne 20. 5. 2014, stížnost č. 11828/11.

[30] Rozhodnutí nizozemského Nejvyššího soudu ze dne 3. 3. 2015, sp. zn. 14/04940. Dostupné online z: http://deeplink.rechtspraak.nl/uitspraak?id=ECLI:NL:HR:2015:434

[31] Rozhodnutí správněprávní sekce nizozemské Rady státu ze dne 4. 3. 2015, sp. zn. 201400944/1/A1. Dostupné z: https://www.raadvanstate.nl/uitspraken/zoeken-in-uitspraken/tekst-uitspraak.html?id $=82862$.

[32] Rozsudek Nejvyššího správního soudu ze dne 21. 9. 2010, čj. 8 As 59/2010-78.

[33] Usnesení Nejvyššího soudu ze dne 22. 8. 2007, sp. zn. 5 Tdo 874/2007.

Toto dílo lze užít v souladu s licenčními podmínkami Creative Commons BY-SA 4.0 International (http://creativecommons.org/licenses/by-sa/4.0/legalcode). 